\title{
JOB SATISFACTION OF EMPLOYEES IN THE HIGHER EDUCATION
}

\author{
Agneš Slavić 314 \\ Julija Avakumović ${ }^{315}$
}

https://doi.org/10.31410/itema.2018.914

\begin{abstract}
The higher education is an important factor of the development of each society. The success of the higher education significantly depends on the job satisfaction of the teachers working there. The cognitive, affective and behavioral reaction of employees - teachers in higher education influences their educational and research work and therefore the success of their students, institutions and society as a whole. The aim of the human resource management (HRM) activities is to achieve the organization's strategic objectives and the satisfaction of its employees in the same time. The role of HRM in the higher education is to implement adequate techniques for the recruitment and selection of candidates, for the training and development of employees and to design compensation system regarding internal and external equity in order to increase employee satisfaction. The aim of this paper is to present the main causes of employee satisfaction of teachers in higher education and effective measures and HRM techniques to increase the job satisfaction of employees in higher education - based on literature review.
\end{abstract}

Keywords: job satisfaction, higher education, staffing, training and development, compensation system

\section{INTRODUCTION}

The education sector of any country has very important role in the society, especially in the creation of knowledge. The transfer of knowledge is performed mostly in higher education institutions. In each social system we have two types of higher education institutions, state and private. (Bodla et al, 2014)

Academic staff plays a key role in determining the success, vision and mission of the higher education institution. High quality academic staff is the source of successful education system. (Stanovska et al, 2017) Academic staff represents the value of the country and the builders of the nation. (Khan et al, 2014)

Academic staff is a key resource in the higher education sector, and have key role in the implementation of the goals of higher education institution. The performance of academic staff is determined by the success of their students and has got impact on students learning. (de Louders Machado et al, 2011)

The quality of higher education does not include only the quality of processes and functions, but also the quality of all employees - teaching and administrative staff. Today, like never

\footnotetext{
${ }^{314}$ Faculty of Economics, Segedinski put 9-11, Subotica, Serbia

${ }^{315}$ Faculty of Economics, Segedinski put 9-11, Subotica, Serbia
} 
before, teaching staff have to be able to recognize what needs should be changed and applied in their work, in interest of adapt to new trends in education. (Wisniewska, Grodowski, 2016) The current trend in education is to offer higher level service, in order to meet the demands of students (users of education service). (Wu et al, 2014)

The Bologna process represents a new era in the development of education system and contributes to the harmonization of similar systems in different countries all over the world, through qualification frame, European Credit Transfer System and diploma supplement. The main focus is on the introduction of the system that has got:

- three levels of education (graduate, master and $\mathrm{PhD}$ studies);

- higher level of teaching quality;

- easier recognition of acquired qualification; and

- acceptable study time. (Wisniewska, Grudowki, 2016)

Today, 46 counties have accepted participation in Bologna process, recommendations of European Cultural Convection (ECC) and the goals of European Higher Education Area (EHEA).

On $2005^{\text {th }}$ year, in the Republic of Serbia, the application of Bologna Declaration officially launched with in that moment new Law of education and forming (ex) Commission of Accreditation. On $2017^{\text {th }}$ year, the newest Law of education has anticipated the establishment of National Accreditation Body, which officially began to work in May $2018^{\text {th }}$.

In the year 2012 ${ }^{\text {th }}$, the Government of Republic Serbia voted for the Action plan for implementing the Development education strategy 2020, with which it defined education system so that "should provide the basic foundation of life and development of each individual, society and state based on knowledge".

\section{THE BASIC CONCEPT OF EMPLOYEES SATISFACTION}

Job satisfaction is an attitude, which manifests at the place of work, as individual behavior of the employee and could have an impact on the organization and organizational behavior. Job satisfaction encourages employees to increase their performance, commitment to the organization, reduce absenteeism and increase interest for profession. It is equally important in private and public sector, in developed and developing countries. (Khan et al, 2014)

In the discipline of organizational behavior, the most interesting attitude towards work is job satisfaction. Like other attitudes, job satisfaction has three basic components: the cognitive component contains what a person believes to know about subject of attitude, the evaluation component refers to how much somebody love or do not love anything (or anybody), and the behavioral component contains a certain predisposition to act in certain direction. Job satisfaction could be viewed as a general attitude towards work, or satisfaction with 5 (five) specific dimension, like as: salary, work as such, promotion opportunity, superior and associates. (Zimanji, Šušnjar, 2007)

Job satisfaction has always been interesting for research, due to its close connection with the employee`s performance, and organizational commitment. (Bodla et al, 2014)

Job satisfaction is multidimensional attitude, because it includes internal qualities (ability, achievement, progress, compensation, cooperation, creativity, independence, ethical values, 
status and working conditions) and external qualities (authority, policies and practice, recognition, responsibility, security and diversity). (Wang, Lee, 2009) Job satisfaction can also be the result of two variables: demographic (age, gender, education level) and work environment, and it could be defined as an emotional, evaluative and cognitive response of an individual on his/her work. (Khan et al, 2014)

Some researches investigate on the factors that affect satisfaction or dissatisfaction with the organization, and examine the impact of human resource practice on job satisfaction. For example, student behavior is related to the satisfaction of teacher, during classes.

Individual performance is based on opportunities, motivation and organization support, while personal characteristic of teachers (gender, age, work experience and education) could be in correlation with job satisfaction. According to research results (Saiti \& Papadopoulos, 2014):

- The age of teaching staff is in correlation with job satisfaction, older staff are more satisfied with goals and workload, while younger staff are more satisfied with salary;

- Low level of job satisfaction is caused by salary and the possibility of personal promotion, while the higher level of job satisfaction is caused by "nature of the job"; and

- The role of leading teacher and working climate are key factors that affect job satisfaction. (adapted by: Saiti \& Papadopoulos, 2014)

In $1985^{\text {th }}$ year, author Paul Spector in his research found correlation between job satisfaction, salary, age of employees and level of organizational performance. (Spector, 1985; Khan et al, 2014)

Job satisfaction is in correlation with numerous aspects of organizational performance, like as: crafts; efficiency and productivity; the relation between employees at the workplace; decision about retire; social responsibility and organizational behavior; "roughness" at the workplace; leadership and personal characteristics. (Saiti \& Papadopoulos, 2014)

\section{THE CAUSES OF SATISFACTION OF EMPLOYEES IN HIGHER EDUCATION}

Job satisfaction represents an emotional response to the current situation on the workplace, with which an employee is faced. Job satisfaction is a perception of an employee between what he/she wants from the job and what the job realistically provides. (Stanovska et al, 2017)

Job satisfaction and motivation of academic staff have got an important role in the quality of education institution and the improvement of students` learning (Stanovska et al, 2017) which are representing future workforce in different areas. (Khalid et al, 2012)

Competitiveness in the education sector depends of that how satisfied the employees with their job, or how they are "involved" and dedicated in the job. How to attract and retain academic staff, especially talent, and managing their performance is the main task of strategic human resource management. (Van den Brink et al, 2013)

Motivation and satisfaction of employees become the basis of modern human resource management, because only an adequate motivation system could help organizations to increase their competitiveness and value. (Early et al, 2011) 
Motivation and satisfaction of academic staff is crucial for their performance and for the quality of higher education institution. (de Louders Machado et al, 2011) We can see on Figure 1, that motivation can be expressed, like a desire for: lecture; research; making to environment; participation in commitments; work in education; and sense of belonging to academic staff. Satisfaction can be expressed as satisfaction with: workplace; higher education institution; the ability to practice teaching; possibilities to practice teaching like academic staff; prestige that brings the teachers` position; and possibility for research work.

Figure 1: Motivation and job satisfaction of academic staff in higher education (adopted from: de Louders Machado et al, 2011)

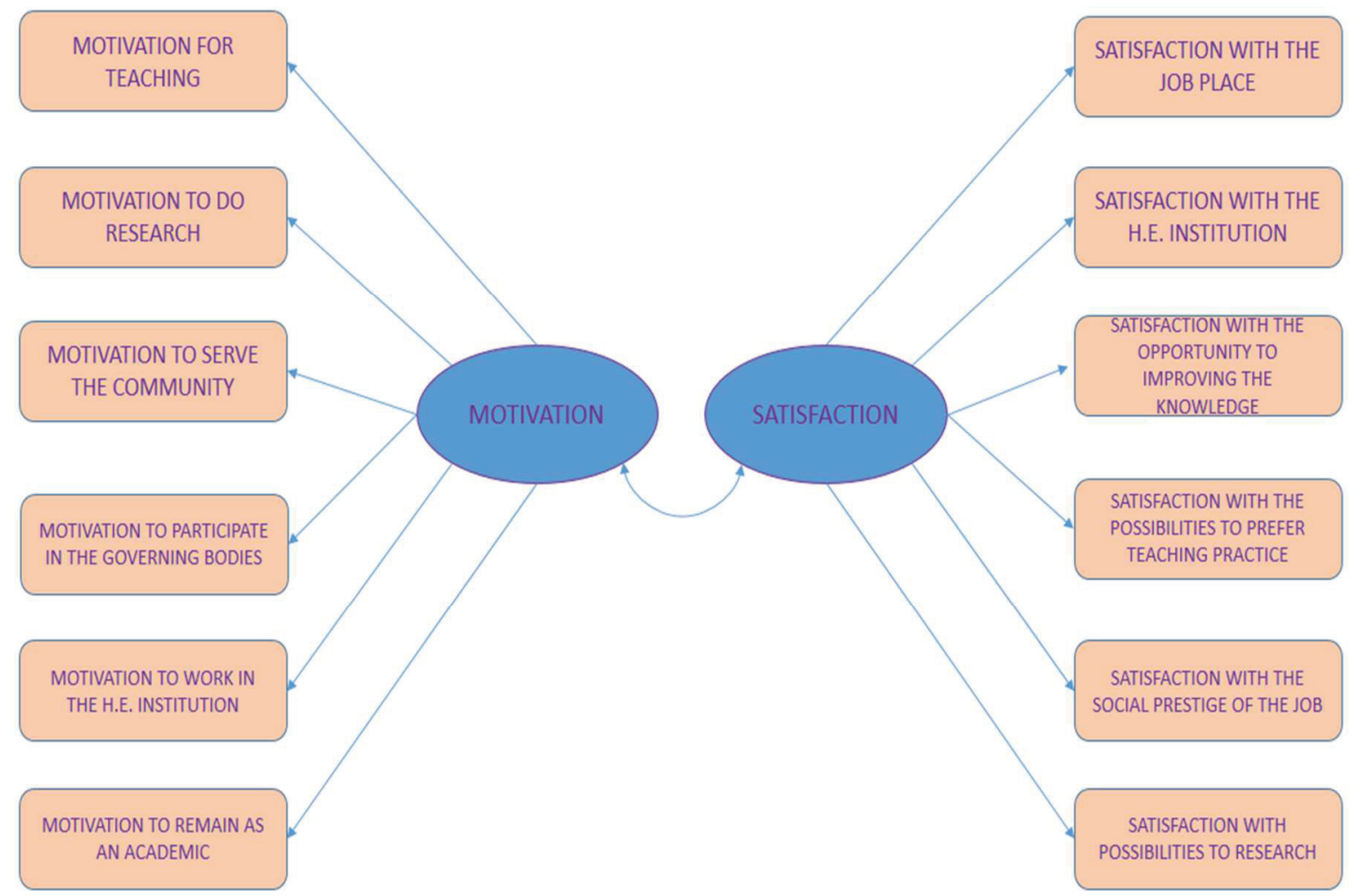

The influence on job satisfaction has got climate of area or country, where the research on employee satisfaction is done. Factors that always will be taken are: workplace maintenance, relationship with associates and working environment. (Luthans, 2005; Stankovska et al, 2017)

Many different factors could have influence on job satisfaction of academic staff and it depends on the area of the research. In some less developed countries, the main causes of job satisfaction may be: regularly incomes, job security and place in society. On the other side, in some developed countries where incomes in all sectors are regular, the main antecedents of job satisfaction of academic staff can be their personal desire for that kind of job, personal promotion and desire for that kind of promotion.

\section{HRM ACTIVITIES AIMING TO INCREASE THE SATISFACTION OF EMPLOYEES IN HIGHER EDUCATION}

There are only a few researches focusing the job satisfaction and factors related to satisfaction or dissatisfaction in an organization, and that examine the effects of different human resource practices on satisfaction. Even though, job satisfaction may be increased by various factors, 
such as compensation, relationship with colleagues and working environment. (Khan et al, 2014)

Academic teaching staff should have certain characteristics, in order to perform its task with quality and achieve more performance. The recommendation is to keep teaching on an interesting and innovative way; to use various innovative techniques during classes and in communicating with students; to be objective; to have tolerance; to work in a "relaxed" atmosphere but to have control; to love working with students; to have knowledge and adequate scientific title; to have ability to learn; to have authority and charisma; to have contacts with business entities; to be dedicated; to conscientiously perform his/her work with respect of ethical principles; to be motivated; if have flexible time to be "just in time"; and to be creative. (Wisniewska, Grudowki, 2016)

Human resource management (HRM) activities: staffing, training and career development, and compensation can have positive or negative influence on job satisfaction. In the following a brief overview the research results of different authors on the influence of HRM activities on job satisfaction will be presented.

The research results on the job satisfaction of academic staff at private and state universities in Portugal are the following:

- $\quad$ satisfaction with the job, (6.7)

- $\quad$ satisfaction with the institution, (5.7)

- $\quad$ satisfied with the chance to improving the knowledge, (5.8)

- $\quad$ satisfied with the adequate skills of teaching practice, (7.0)

- $\quad$ satisfied with reputation in society, carried by teachers` profession, (6.3)

- $\quad$ satisfied with teaching activities, (6.7) and

- $\quad$ satisfied with possibilities to research. (5.5). (de Louders Machado et al, 2011)

Based on the results (which have given in brackets), authors concluded - that if the level of job satisfaction of academic staff is higher, the possibility for achieving higher performance is higher, as well as more quality work with the students.

Some authors point out different studies on human resource management practice, where focus is on the environment that promotes quality and cost reduction, focused on: innovation, recruitment skills and labor policy, performance measurement and market enhancement. Some previous researches classified human resource practices on internal and external. Internal represents internal skills, and external is focused on strategic integration. (Abdullah et al, 2009; Khan et al, 2014) External factors are training and development, team work, job security, productivity and flexibility of the organization, and these represent relationship between high performance and human resource practice. In the same studies, compensation is the next factor of human resource practice. There is an inseparable connection between compensation and job satisfaction.

At federal Urdu University of Science and Technology, Islamabad, Pakistan, a study was conducted about the impact of human resource management practice (compensation, staff training and monitoring of staff) on job satisfaction and impact on work quality and performance. Career planning has strong significance on the HRM practice. It proved that an employee, who actively participates in the selection of the development of his/her further career, later has got higher level of job satisfaction. The results indicate that compensation as human resource activity has a positive relationship with job satisfaction. Monitoring, 
empowerment and work placer are important for retention of academic staff at faculties. This could be implemented at higher education institutions, because an adequate rewarding strategy can contribute to increasing the overall performance of employees and education institution, which further fosters a good relationship between employee and work place. (Khan et al, 2014)

At one faculty in Republic of Serbia, in a research on the level of employees' satisfaction in higher education and the influence of different factors on job satisfaction (Popovic et al, 2015), authors used their Job Satisfaction Questionnaire. One of the questions asked: Is the job you are doing for you? The answer provided: a) material existence, b) providing professional preferences and interests, and c) both. The majority of respondents (78\%) work both for material existence and for realization of professional preferences and interest. The results show that employees are the most satisfied with working hours, but consider that the reward system does not stimulate dedication and creativity of employees. In regards of development opportunity (career development), employees have the view that they are approximately satisfied. Compensation is the most disadvantageous for the employees regardless of their professional qualification, title and years of life and work (in this case, we should take the factor that national standard is very low in the Republic Serbia, and because that compensation like human resource activity has got negative impact on job satisfaction). The employees in higher education institutions work under good working conditions and environment. The need for personal affirmation and training emphases is in interest to progress at work and on that way contributes to improving performance of faculty. This is why career development as a HRM activity has got positive impact on job satisfaction.

Authors Nandan and Krishna present the model, where job satisfaction is the sum of the functions of the influence of the regression coefficient and factors of motivation, selfemployment work, labor relation, policy and procedure, payment and benefits, personal development, stress, conflict strategy, teacher performance, researcher performance, strength and opportunity, weaknesses and threads, and statistical error. Authors found that only stress, weaknesses and threads had a negative impact on job satisfaction. Further analysis, indicates that the business position and demographic characteristics of academic staff - like staff have impact on job satisfaction, because the level of job satisfaction of academic staff with $\mathrm{PhD}$ degree is higher, than for academic staff without $\mathrm{PhD}$ degree. Job satisfaction is higher for academic staff that has higher title on workplace, it means that full time professors have got higher level of job satisfaction than part time professors, and part time professors have got higher level of job satisfaction than associate professors and assistants. Job satisfaction depends on age, too, as younger academic staff (less than 45 year old) are more motivated for teaching and researching, and have higher level of job satisfaction. Older academic staff (more than 45 year old) spend more time with family and for other duties, and that could decrease their level of job satisfaction. The results of this study also present that academic teaching staff with lower work experience (till 10 years) have got greater motivation for teaching and researching to provide and develop their career, because that it's possible to conclude that job satisfaction is on higher level for employees with less work experience. Stress can negatively affect job satisfaction and it is more present as the factor for employees with more year of work experience. The effect of compensation on job satisfaction manifests in performance evaluation practice, as is if evaluation of performance is better, the job satisfaction is higher. (Nandan, Krishna, 2013)

Human resource management policy has direct positive effect on work result and organizational performance. Results are related to competences, cooperation with management, cooperation between employees, motivation, satisfaction, commitment and retention of staff. Training and 
development are increasing skills and competencies of employees, but satisfaction is increasing through training at workplace. Training and development activities minimize the gap between real and desired performances. In their research, authors analyzed relationship of human resource management activities, training and development and compensation, with job satisfaction. Result represents that training and development, and compensation, like HRM activities have got positive impact on job satisfaction. The coefficient of determination indicates that increasing of training and development in only $1 \%$, results with increasing of job satisfaction in $17 \%$. Assessment of the performance, has significantly related with the job satisfaction. Recommendation is that promotion, incentive and honor should be based on performance evaluation results, because fair compensation system (salary, benefits) could significantly increase job satisfaction. (Bodla et al, 2014)

At State University of Skopje, Stankovska et al (2017) used JSS (Spector, 1985) questionnaire to measure job satisfaction. The questionnaire consists of 36 items, and 9 of them (salary, promotion, supervision, benefits, rewards, procedure, associates, nature of job, and communication on workplace) are related to the assessment of employees 'attitude about job. The results indicate that academic teaching staff is satisfactory with their own work. The most satisfied are full time professors and the least satisfied are assistants. Academic staff is satisfied with their salary and possibility of promotion, but they are not satisfied with rewarding and communication. The study showed that the staff is highly motivated and that motivation has a direct impact on job satisfaction.

Authors conclude that the main determinate of job satisfaction is compensation (payment). In the Republic of Serbia, the professional characteristics of academic teaching staff is regulated by Law of higher education from $2017^{\text {th }}$ years (articles 74-87), while the procedure for recruitment and selection of candidates is regulated by Labor Law and some sub-legal acts of higher education institution. Very often, the training and career development are limited by financial resources of the higher education institution. In the state owned higher education institutions, the compensation (salary and benefits) is limited to the budget of the Republic of Serbia. The only possibility for extra funds is from the institutions own income, but allocation of that financial resources depends of management policy.

\section{CONCLUSION}

The educational sector of any country has a unique significance, especially in creation of knowledge. The competitiveness of the educational sector depends of the satisfaction of employees and their commitment.

The main strategic question of human resource management is: How to attract and retain quality teaching staff?

The academic staff is more satisfied with their work environment, if their colleagues respect their research work.

Management of higher education institutions should put accent on the impact assessment on which promotion, incentives, acknowledgement and appreciation of employees could be based. It should be noted that various bonus packages increase the satisfaction of employee.

Adequately designed human resource management practice is very important for job satisfaction of academic teaching staff, regardless of is it in private or state ownership. 
Such as presented in the paper, and based on researches of various authors, we can conclude that human resource management activities have a significant impact on the satisfaction on academic staff. One of the important factors related to the job is the position that employees have in higher education institution. In the process of recruitment and selection of academic staff, rules and procedures for advertising vacant position and selection of candidate, which are regulated by the Law in the Republic of Serbia have an important role. Employees who have the possibility of adequate training and active participation in the selection of their further career development possibilities, have got higher level of job satisfaction. The internal and external equity of the compensation system has a positive impact on job satisfaction, which with additional benefits could be a requirement for retaining academic staff at higher education institutions.

\section{REFERENCES}

1. Abdullah, Z., Ahsan, N., and Alam, S. S.: The Effect of Human Resource Management Practices on Business Performance Among Private Companies in Malaysia. International Journal of Business and Management, 4(6), 2009.

2. Bodla, Hussain, Chen: Determinants of Job Satisfaction in Academic Professionals of Pakistan, Sukkur IBA, Journal of Management and Business, vol.1, Oct. 2014.

3. de Lourdes Machado, Soares, Brites, Ferreira, Rocha Gouveia: A look to academics job satisfaction and motivation in Portuguese, higher education institutions, Procedia - Social and Behavioral Sciences 29, p.p. 1715 - 1724, Portugal, 2011.

4. Furnham,A.:The Psychology of Behavior at Work, The Individual in the organization, Osychology Press,p. 718.,1997.

5. Khalid,S.,Irshad,M.Z.,\&Mahmood,B.:Job Satisfaction among Academic Staff: A Comparative Analysis between Public and Private Sector Universities of Punjab, Pakistan. International Journal of Business and Management 7 (1). 2012.

6. Khan, F., Yussof, R., Khan, A.: Effect of Human Resource Practices on Job satisfaction in Pakistan, Sains Humanika, 1:1 p.p., 53-57, 2014.

7. Luthans, F.:Organizational behavior, McGraw-Hills.2005

8. Nandan, Krishna: Determinants of job satisfaction of Faculty in Higher Education, The Indian Journal of Industrial Relations, Vol. 49. No. 1, July 2013.

9. Popovic, Maletic, Paunovic: Employee Satisfaction Survey in Function of Business Improvement, Management, FON, vol. 76, Belgrade, 2015.

10. Prvulović S., Šekularac I., Živković Ž.: Employee motivation as a factor of the business success. Business policy, 38(1-2), p. 54-65., 2009.

11. Saiti, Papadopoulos: School teachers' job satisfaction and personal characteristics: A quantitative research study in Greece, International Journal of Educational Management, vol. 29 Issue: 1, pp.73-97., 2015.

12. Spector, P.E.: Measurement of human service staff satisfaction: development of the job satisfaction survey, American Journal of Community Psychology, Vol. 13 No. 6, pp. 693713. 1985.

13. Stankovska, Angelkoska, Osmani, Grncarovska: Job Motivation and Job Satisfaction among Academic Staff in Higher Education, Current Business and Economics Driven Discourse and Education: Perspectives from Around the World BCES Conference Books, Volume 15. Sofia, Bulgaria, 2017.

14. Van den Brink, M., Fruytier, B., \& Thunnissen, M.: Talent management in academia: performance systems and HRM policies. Human Resource Management Journal, 23(2), 2013. 
15. Wang, G. \& Lee, P. D.: Psychological environment and job satisfaction: an analysis of interactive effects. Journal of Global Strategic Management, 34(3), 271-296. 2009.

16. Wisniewska, Grudowski: High-quality academic teachers in business school. The case of The University of Gdansk, Poland, Total Quality Management, Vol. 27, No. 10, 11581170, 2016.

17. Wu, S., Lin, C., Wu, S., Chuang, C.-L., \& Kuan, H. Y.: Factors affecting quality of service in schools in Hualien, Taiwan. Procedia - Social and Behavioral Sciences, 116(21), 11601164., 2014.

18. Zimanji, Šušnjar: Organizaciono ponašanje, Ekonomski fakultet, Subotica, 2007. 